\title{
$\mathrm{Sn}-\mathrm{X}$ 系合金における初晶晶出時の過冷度と初晶の体積率
}

\author{
吉村 龍* 長岡 賢* 長友康浩* 江阪久雄 篠塚 計
}

防衛大学校機能材料工学科

J. Japan Inst. Met. Mater. Vol. 81, No. 2 (2017), pp. 80-88

(C) 2016 The Japan Institute of Metals and Materials

\section{Undercooling for Nucleation and Volume Fraction of Primary $\beta$-Sn Phase in Sn-X Alloys}

\author{
R. Yoshimura*, S. Nagaoka*, Y. Nagatomo*, H. Esaka and K. Shinozuka \\ Department of Materials Science and Engineering, National Defense Academy, Yokosuka 239-8686
}

\begin{abstract}
The undercooling for nucleation and volume fraction of primary $(\beta-\mathrm{Sn})$ phase has been investigated in $\mathrm{Sn}-\mathrm{X}$ hypoeutectic alloys where $\mathrm{X}$ were $\mathrm{Pb}, \mathrm{Ag}, \mathrm{Al}, \mathrm{Bi}, \mathrm{Cu}$ and $\mathrm{Zn}$. The purities of raw materials were $4 \mathrm{~N}$ and the solute content of the alloy was set for the volume fraction of primary phase to be from 0.3 to 0.45 , according to the equilibrium phase diagram. Thermal history was measured during solidification of $5 \mathrm{~g}$ alloy sample at a cooling rate of $0.05 \mathrm{~K} / \mathrm{s}$, with fine $\mathrm{K}$-type thermocouple. The volume fraction of primary $(\beta-\mathrm{Sn})$ phase was measured on the longitudinal cross section of the sample. When the solute elements were $\mathrm{Pb}, \mathrm{Ag}, \mathrm{Al}, \mathrm{Bi}$ and $\mathrm{Cu}$, the undercooling was more than $5 \mathrm{~K}$ and was large. Furthermore, the volume fraction of primary $(\beta-\mathrm{Sn})$ was larger than the equilibrium value. On the other hand, when the solute element was $\mathrm{Zn}$, the undercooling for the nucleation of primary $(\beta$-Sn) was $0.9 \mathrm{~K}$ and quite small. In addition to this, the volume fraction of primary phase agreed with the equilibrium value. [doi:10.2320/jinstmet.J2016041]
\end{abstract}

(Received July 5, 2016; Accepted October 20, 2016; Published December 16, 2016)

Keywords: lead-free solder, $\beta$-tin, volume fraction, lever rule, undercooling, equilibrium, solid-liquid interfacial energy

\section{1. 緒言}

世界的に $\mathrm{Pb}$ の使用が抑制され始めたことから, $\mathrm{Pb}$ を含ま ない $\mathrm{Pb}$ フリーはんだの研究開発が進められ $れ^{1-4)}$, 現在では多 くの電化製品に使用が広まっている。しかし，はんだ付け特 性や耐久性あるいは経済性の観点から， $\mathrm{Sn}-\mathrm{Pb}$ 系はんだと同 等とは言えないため, 様々な機関で高性能な鉛フリーはんだ の研究開発が進められている ${ }^{5-7)}$.

凝固したままで使用されることから，はんだ接合部では凝 固組織制御が特に重要である。近年これに関して新たな指摘 がなされた. Snugovsky ら ${ }^{8)}$ は比較的冷却速度の大きい条件 下で $\mathrm{Sn}-\mathrm{Ag}-\mathrm{Cu}$ 系 3 元合金において 2 つの 2 元共晶が見られ ると報告した。本来, 単純な 3 元共晶系合金である $\mathrm{Sn}-\mathrm{Ag}^{-}$ $\mathrm{Cu}$ 系では, 初晶に引き続き 2 元共晶が晶出し, 最後に 3 元共 晶が晶出して凝固を完了する。このような異常組織ははんだ 接合部の機械的性質の不均一につながり, 接合強度の劣化に 直結する. Takamatsu $ら^{9,10)}$ は $\mathrm{Sn}-1.0 \mathrm{Ag}-0.5 \mathrm{Cu}$ 合金の初晶 $(\beta-\mathrm{Sn})$ 晶出後の樹間液相部を詳細に観察し, $\mathrm{Ag}$ 濃度の高い 領域および $\mathrm{Cu}$ 濃度の高い領域があることを見出している。そ してこれは初晶 $(\beta-\mathrm{Sn})$ が相対的に多く晶出し, 初晶晶出後の 液相が共晶組成以上に濃化するためと推測した。初晶が過大 に晶出すれば, 固液共存相あるいは樹間液相の流動性を低下 させるため, 引け巣や割れなどの欠陥につながり, 接合部の 信頼性低下に直結する. また, 初晶 $(\beta-\mathrm{Sn})$ の晶出量が平衡状

\footnotetext{
* 防衛大学校大学院生 (Graduate Student, National Defence Academy)
}

態図に基づく予測值とずれることは合金設計の精度にも直結 することであり，早急に解明すべき課題である.

筆者ら ${ }^{11)}$ は初晶 $(\beta-\mathrm{Sn})$ の体積率 $\left(\right.$ 以下 $\left.f_{\beta-\mathrm{Sn}}\right)$ が平衡状態図の 予測值よりも大きくなるのは, 初晶晶出時の過冷度が影響す ると考えて, $\mathrm{Sn}-\mathrm{Ag}$ 系合金を用いて過冷度を変更する実験を 行った。その結果, 制御できる範囲内ではどの過冷度でも $f_{\beta-S n}$ は予測值よりも大きいものの, 過冷度が大きい方が $f_{\beta-S n}$ は大きくなることを明らかにした，そこで本研究では, $\mathrm{Sn}-\mathrm{X}$ 系 $(\mathrm{X}=\mathrm{Pb}, \mathrm{Ag}, \mathrm{Al}, \mathrm{Bi}, \mathrm{Cu}, \mathrm{Zn})$ の 2 元共晶型の合金を用い て凝固実験を行い, 初晶 $(\beta-\mathrm{Sn})$ の晶出時の過冷度と初晶 $(\beta-\mathrm{Sn})$ の $f_{\beta-\mathrm{Sn}}$ の関連性について調べた.

\section{2. 実 験 方 法}

\section{1 母合金作成方法}

本実験では $\mathrm{Sn}$ 基の亜共晶合金である， $\mathrm{Sn}-\mathrm{X}$ 系合金を用い た. $\mathrm{Sn}-\mathrm{X}$ 系合金の平衡状態図の一部を Fig. 1 に模式的に示 す.これらの二元共晶合金の共晶組成 $\left(C_{\mathrm{E}}\right)$, 共晶温度での初 晶 $(\beta-\mathrm{Sn})$ への固溶量 $\left(C_{\beta}\right)$, 共晶温度 $\left(T_{\mathrm{E}}\right)$ など, 今回採用した 合金系の基礎デー夕12-17) を Table 1 にまとめる. 今回の研究 では第 2 元素である $\mathrm{X}$ として, $\mathrm{Pb}, \mathrm{Ag}, \mathrm{Al}, \mathrm{Bi}, \mathrm{Cu}$ そして Zn を選択した. Table 1 に示した基礎デー夕に基づき, 平衡 状態図通りに凝固が進行して共晶温度になれば初晶 $(\beta-\mathrm{Sn})$ の 晶出量が「てこの法則」によって決定される. その值が $0.3-$ 0.45の範囲に入るようにそれぞれの合金の組成を決定した．第 2 元素の含有量 $\left(C_{\mathrm{X}}\right)$, 液相線温度 $\left(T_{\mathrm{L}}\right)$ および共晶温度での初 晶 $(\beta-\mathrm{Sn})$ 相の晶出量の予測值 $\left(f_{\beta-\mathrm{Sn}}^{0}\right)$ も Table 1 に記入した. 


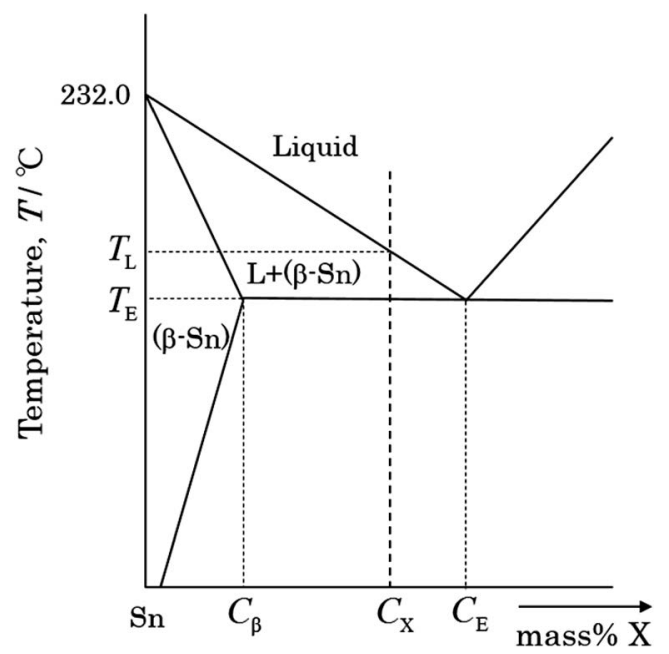

Fig. 1 A schematic drawing of a part of equilibrium phase diagram of $\mathrm{Sn}-\mathrm{X}$ binary system and principal parameters for estimation of the volume fraction of primary $(\beta-\mathrm{Sn})$ phase.

Table 1 Parameters of binary eutectic alloys used in this study and equilibrium values of volume fraction of primary $(\beta-\mathrm{Sn})$ phase.

\begin{tabular}{crrrrrrr}
\hline Alloy & \multicolumn{1}{c}{$C_{\mathrm{E}}$} & $C_{\beta}$ & $T_{\mathrm{E}}$ & $C_{\mathrm{X}}$ & $T_{\mathrm{L}}$ & $f_{\beta-\mathrm{Sn}}^{0}$ & Ref. \\
\hline $\mathrm{Sn}-\mathrm{Pb}$ & 38.1 & 2.5 & 183 & 25.0 & 195.0 & 0.37 & $12)$ \\
$\mathrm{Sn}-\mathrm{Ag}$ & 3.5 & 0 & 221 & 2.0 & 225.7 & 0.43 & $13)$ \\
$\mathrm{Sn}-\mathrm{Al}$ & 0.6 & - & 228 & 0.4 & 229.3 & - & $14)$ \\
$\mathrm{Sn}-\mathrm{Bi}$ & 57.0 & 21.0 & 139 & 45.0 & 158.0 & 0.33 & $15)$ \\
$\mathrm{Sn}-\mathrm{Cu}$ & 0.9 & 0 & 227 & 0.6 & 228.7 & 0.33 & $16)$ \\
$\mathrm{Sn}-\mathrm{Zn}$ & 8.8 & 0.3 & 198.5 & 6.0 & 206.0 & 0.33 & $17)$ \\
\hline
\end{tabular}

ここで, mass\%で記述してある平衡状態図を用いて推定する 初晶の割合は質量比であるが, 本実験で用いた合金系では体 積割合と質量割合の差がわずかであるため, これらは同一と して解析を進めた ${ }^{18)}$.

ここで $\mathrm{Sn}-\mathrm{Al}$ 系については共晶温度での初晶 $(\beta-\mathrm{Sn})$ への $\mathrm{Al}$ の固溶量がはっきりとしない ${ }^{14,19,20)}$ ため, 初晶の晶出量につ いての検討からは除外した。 また, $\mathrm{Sn}-\mathrm{Bi}$ 系では共晶温度で の初晶 $(\beta-\mathrm{Sn})$ への固溶量について $25 \mathrm{mass} \% \mathrm{Bi}$ と報告してい る例 ${ }^{21,22)}$ がある一方で, 10 mass\% Bi と報告している例23,25) もある。ここでは文献15)に従い， 21 mass\% Bi として検討を 進めた。

$\mathrm{Ar}$ 雲囲気下での $300^{\circ} \mathrm{C}$ に保持をした電気炉を用いて, 外径 $50 \mathrm{~mm}$, 内径 $40 \mathrm{~mm}$, 全長 $100 \mathrm{~mm}$ のアルミナるつぼで $\mathrm{Sn}$ を融解させた. その後, 第 2 元素を添加し 30 分間保持した. その間, 融液の不均一化を避けるため10分間隔で十分に攪拌 した. その後, 内径 $4 \mathrm{~mm}$ のパイレックスガラス管に溶融合 金を吸引し, 急冷凝固させた。温度降下後, ガラス管を粉砕 し，母合金とした。なお，本実験で使用した金属材料の純度

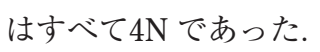

\section{2 凝固実験方法}

実験装置の模式図を Fig. 2 に示す。電気炉は外径 $50 \mathrm{~mm}$, 内径 $42 \mathrm{~mm}$, 全長 $240 \mathrm{~mm}$ の炉心管にカンタル線を巻いたも のである、るつぼは外径 $15 \mathrm{~mm}$, 内径 $11 \mathrm{~mm}$, 全長 $100 \mathrm{~mm}$ のアルミナ製であり，るつぼに熱電対 (K-type) と Sn-X 合金

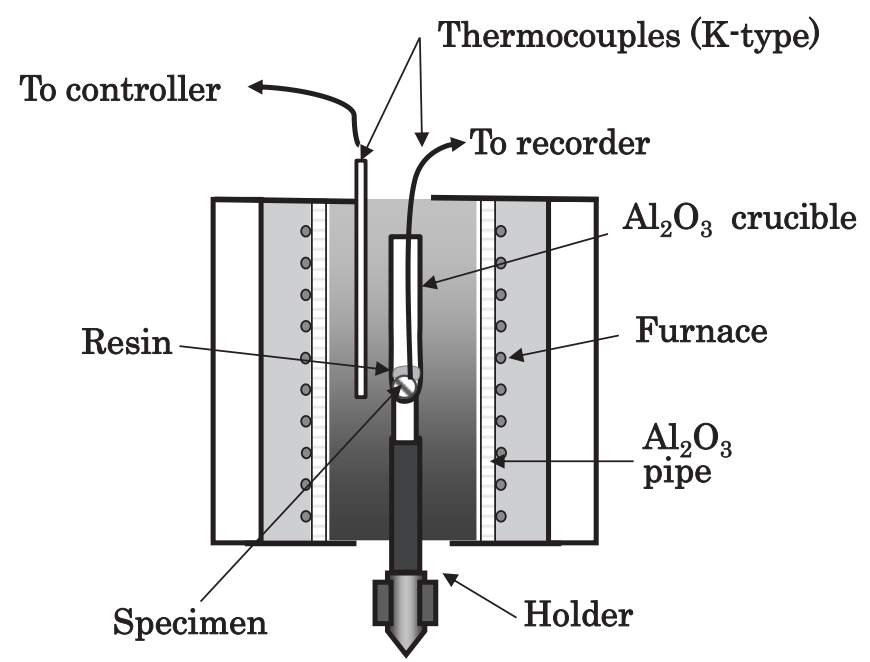

Fig. 2 A schematic drawing of experimental apparatus for measuring the thermal histories during solidification.

$5 \mathrm{~g}$, そして酸化防止のために松脂を入れ, 電気炉内に固定し 実験を行った. 熱電対は外径 $1.2 \mathrm{~mm}$, 内径 $0.3 \mathrm{~mm}$ のつ穴 のアルミナ製絶縁管に $0.1 \mathrm{~mm} \phi$ のアルメル線とクロメル線を 通したものであり, 合金試料のほぼ中央部の温度を直接測定 できるようにアルミナセメントで固定した. 熱電対の起電力 データ採取の間隔は $0.5 \mathrm{~s}$ とした. 熱電対先端の溶解を防ぐ ため, アルミナセメントで薄くコーティングした ${ }^{26)}$. 松脂は 金属試料と比べて融点が低く, 比重も小さい. さらに, 金属 と混じり合わないため溶融金属と䨌囲気ガスの間に液膜を形 成し, 金属試料の酸化を防止する.

電気炉の温度は外部コントローラーで管理した。室温から $0.1^{\circ} \mathrm{C} / \mathrm{s}$ で $300^{\circ} \mathrm{C}$ になるまで昇温後, 10 分間一定に保持した後, $0.05^{\circ} \mathrm{C} / \mathrm{s}$ の冷却速度で降温した. 温度降下の際, 初晶 $(\beta-\mathrm{Sn})$ の晶出の際の復熱および共晶凝固での温度停滞が見られた。

室温まで冷却後, 試料を取り出し, 初晶 $(\beta-\mathrm{Sn})$ の体積率 $\left(f_{\beta-S n}\right)$ を測定するために, 試料の中央縦断面を観察した。観 察のために, \#4000までの $\mathrm{SiC}$ 耐水研磨紙で研磨後, アルミナ スラリーによる研磨を行い, 希王水 (蒸留水 $100 \mathrm{ml}$, 塩酸 15 $\mathrm{ml}$, 硝酸 $5 \mathrm{ml}$ ) を用いてエッチングした. その後, 試料の光 学顕微鏡像 $(\mathrm{OM}$ 像 $)$ を撮影した.

初晶 $(\beta-\mathrm{Sn})$ 相と共晶 $(\beta-\mathrm{Sn})$ 相の自動判別は困難であるた め, 一度トレーシングペーパーに初晶 $(\beta-\mathrm{Sn})$ 相の情報のみを 書き写し，画像処理ソフトを用いて全体に占める初晶 $(\beta-\mathrm{Sn})$ の面積率を算出した，本実験の範囲内では初晶がランダムか つ試料全体に分散していたため, 縦中央断面の上部, 中部, 下部の 3 か所からランダムサンプリングを行い, 初晶の面積 率を求め, それらの平均值とした。 なお, 対象としている相 が試料中にランダムに分布している場合は，ある断面での対 象とする相の面積率は体積率に等しいことが知られているた め27), これに従った.

\section{3. 実 験 結 果}

\section{$3.1 \mathrm{Sn}-\mathrm{X}$ 合金の熱履歴測定結果}

Fig. 3 に Sn-25 mass\% Pb により得られた凝固時の熱履歴 


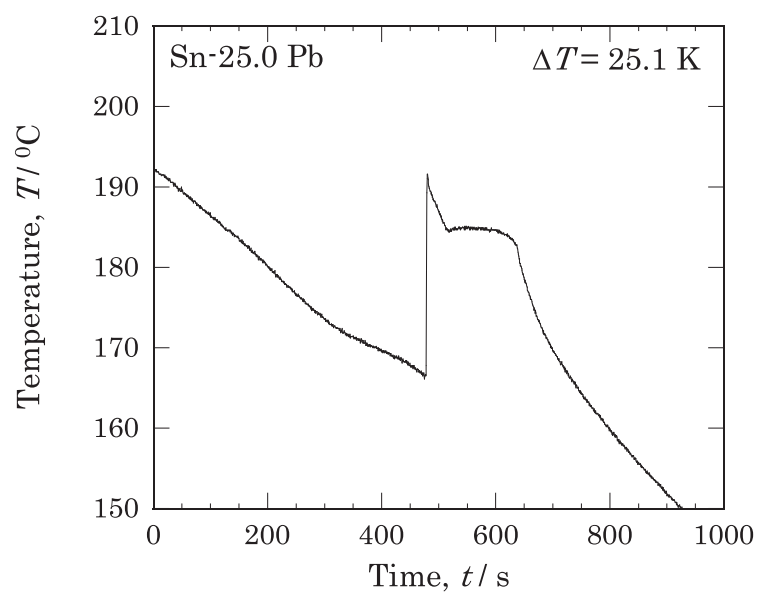

Fig. 3 Thermal history obtained in $\mathrm{Sn}-25$ mass $\% \mathrm{~Pb}$ alloy.

を示す，横軸は時間であり，初晶の晶出や共晶凝固の現象が 読み取れるように時間幅は適宜調整した。Sn-25 mass\% Pb の液相線温度 ${ }^{12)}\left(195^{\circ} \mathrm{C}\right)$, さらに共晶温度 ${ }^{12)}\left(183^{\circ} \mathrm{C}\right)$ を超えて $166.5^{\circ} \mathrm{C}$ まで泠却している。 その間は電気炉の制御通り, $0.05^{\circ} \mathrm{C} / \mathrm{s}$ の速度で冷却していることがわかる. $166.5^{\circ} \mathrm{C} て ゙$ $(\beta-\mathrm{Sn})$ の核生成に伴う復熱が起こり, 約 $191.6^{\circ} \mathrm{C}$ まで急激に上 昇した。最高到達温度は液相線温度よりも低かった。 その後, 再度温度低下し, 共晶凝固に伴う温度停滞が見られた。 なお， 共晶凝固の開始にあたり, わずかに過冷したことが忍められ る。また，実測からは共晶温度は $185.1^{\circ} \mathrm{C}$ と読み取れる。この 実験で用いた測温系では真の值よりも約 $2{ }^{\circ} \mathrm{C}$ 高く測定できて いたと考えられる。ここで, 初晶の核生成のための過冷度の 実測值 $\left(\Delta T_{\text {exp }}\right)$ として, 復熱を開始した最下点と復熱後の最高 点との温度差と定義する。これに従えば，Fig. 3 に示した例 では， $\Delta T_{\exp }$ は $25.1 \mathrm{~K}$ であった。 なお，実験的な過冷度の決 定法については4.1で詳述する.

Sn-2 mass\% Ag で得られた熱履歴の一例を Fig. 4 に示す. 本合金の共晶温度 ${ }^{13)}\left(221^{\circ} \mathrm{C}\right)$ 以下の $197.6^{\circ} \mathrm{C}$ まで過冷した後, 初晶の晶出に伴う復熱が起こり， $225.0^{\circ} \mathrm{C}$ まで復熱した。そのの 後, 凝固開始時の過冷現象の後, 共晶温度での停滞が見られ た。全体的には Fig. 3 に示した $\mathrm{Sn}-\mathrm{Pb}$ 合金と大きく異なる点 は見られなかった。本合金の共晶温度は $222.0^{\circ} \mathrm{C}$ と読み取れる が，共晶温度で比較すると，本測温系では真の温度よりも 1 $\mathrm{K}$ 高く測定できたものと判断できる。 また， $\Delta T_{\exp }$ は $27.4 \mathrm{~K}$ であった。

Sn-0.4 mass\% Al の熱履歴を Fig. 5 に示す．やはり本合金 系の共晶温度 ${ }^{14)}\left(228^{\circ} \mathrm{C}\right)$ 上りも温度が下がり，220.7 ${ }^{\circ} \mathrm{C}$ で初晶 の核生成に伴う復熱が観測され，本合金の液相線温度 ${ }^{14)}$ より も少し高い $231.6^{\circ} \mathrm{C}$ まで温度が上昇した。 その後, 緩やかな冷 却が続き，本合金系では共晶反応での明確な温度停滞は見ら

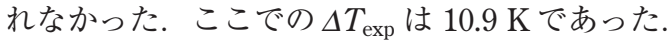

Fig. 6 に Sn-45 mass\% Bi の熱履歴の一例を示す．本合金 の液相線温度 ${ }^{15)}\left(158^{\circ} \mathrm{C}\right)$ 以下の $150.7^{\circ} \mathrm{C} て ゙$ 初晶が核生成・成長 したと思われ， $156.1^{\circ} \mathrm{C}$ まで復熱した。復熱の様子が Fig. 2 か ら Fig. 4 に示した合金系とは異なる。すなわち，速やかに温 度が上昇するのではなく, 約50秒かけて緩やかに復熱したこ とが特徴として挙げられる。 その後, 温度の下降に転じ，共

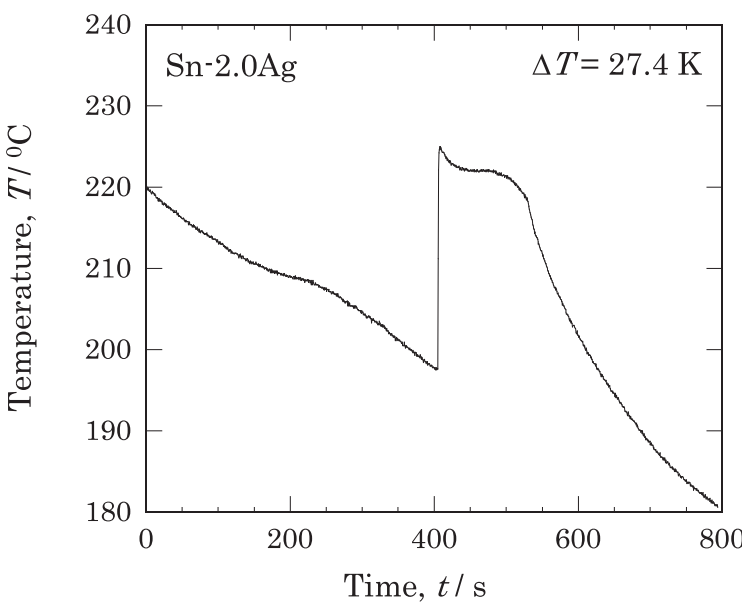

Fig. 4 Thermal history obtained in Sn-2 mass\% Ag alloy.

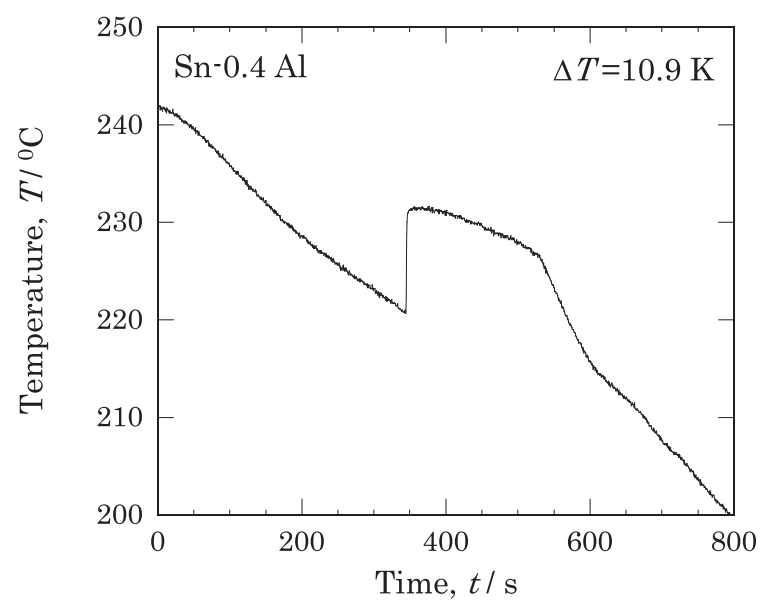

Fig. 5 Thermal history obtained in Sn- 0.4 mass \% Al alloy.

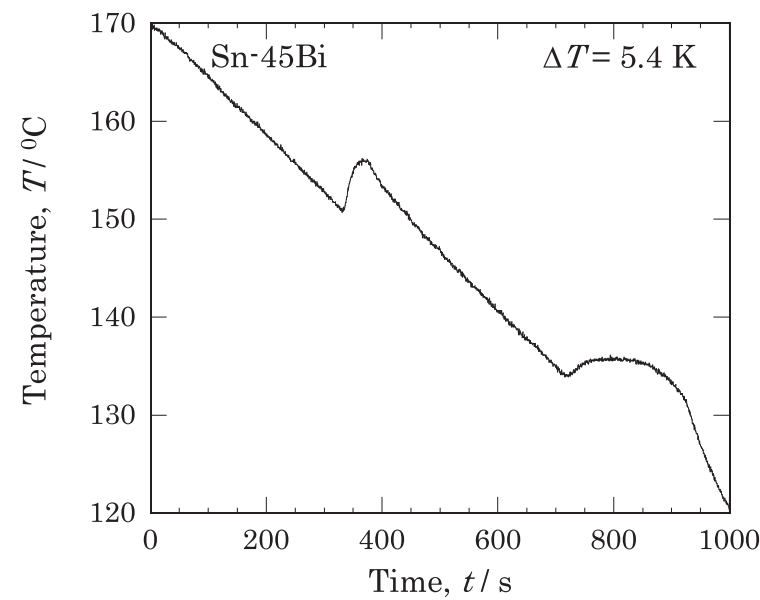

Fig. 6 Thermal history obtained in Sn-45 mass \% Bi alloy

晶凝固の開始に際して比較的大きな過冷度が観測された。ま た，共晶温度で比較すると，平衡状態図の值 ${ }^{15)}\left(139^{\circ} \mathrm{C}\right)$ よりも $2.9 \mathrm{~K}$ 低く測定できていたと判断できる。 なお，本合金系での $\Delta T_{\exp }$ は $5.4 \mathrm{~K}$ であった.

Sn-0.6 mass\% Cu で得られた熱履歴を Fig. 7 に示す．本合 金の共晶温度 $\left(227^{\circ} \mathrm{C}\right)^{16)}$ 以下の $224.6^{\circ} \mathrm{C}$ まで過冷したのち, 初 晶の晶出に伴う復熱が起こり，液相線温度よりも少し高い 


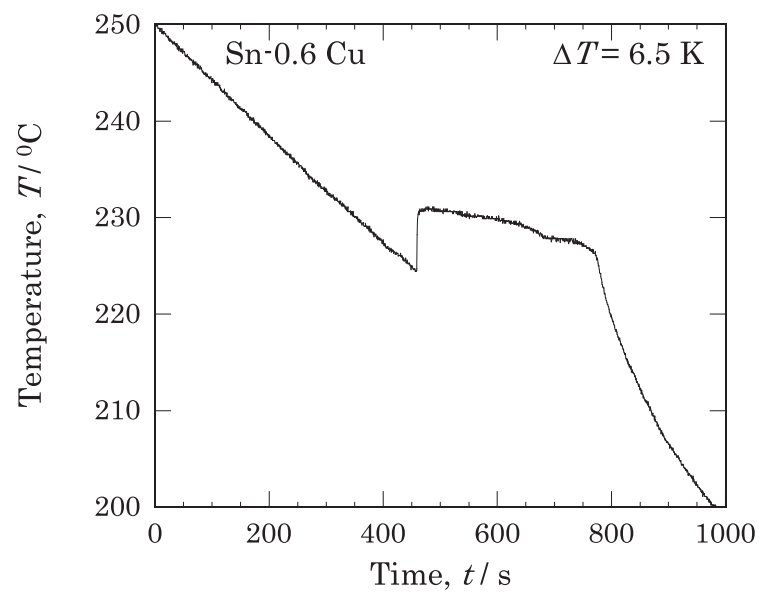

Fig. 7 Thermal history obtained in $\mathrm{Sn}-0.6$ mass $\% \mathrm{Cu}$ alloy.

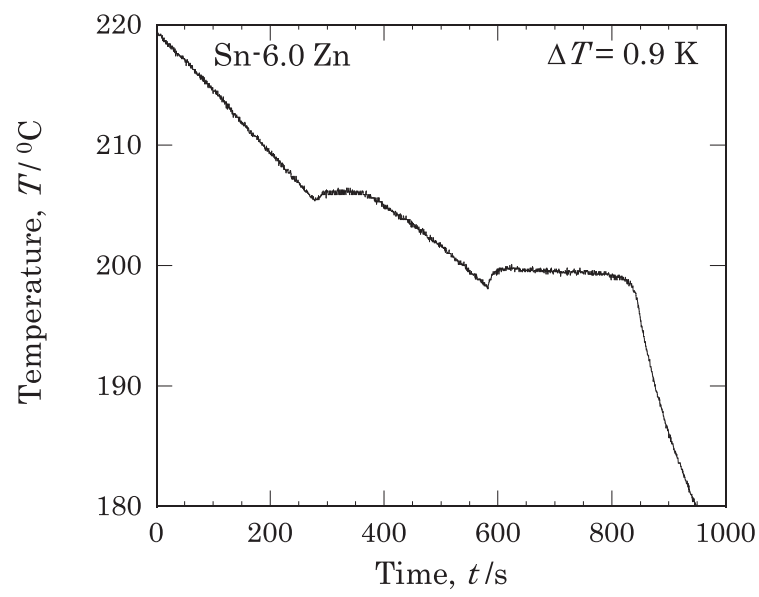

Fig. 8 Thermal history obtained in Sn-6 mass \% Zn alloy.

$231.1^{\circ} \mathrm{C}$ まで上昇した，その後, 共晶温度と考えられる $228.1^{\circ} \mathrm{C}$ で停滞が見られた，共晶温度で比較すると，本測定系では 1.1 $\mathrm{K}$ 高く測定できていたと判断できる。 なお，本合金系での $\Delta T_{\exp }$ は $6.5 \mathrm{~K}$ であった。

Sn-6 mass \% Zn で得られた熱履歴を Fig. 8 に示す. 本合金 の液相線温度 ${ }^{17)}\left(206^{\circ} \mathrm{C}\right)$ を超えて冷却が進み, $205.4^{\circ} \mathrm{C}$ で初晶 $(\beta-\mathrm{Sn})$ の核生成・成長が起こったと考えられる. その後, 緩 やかに温度が上昇し, $206.3^{\circ} \mathrm{C}$ まで復熱した。 その後, 冷却に 転じ, 共晶凝固開始時のわずかな過冷を観測した後, 共晶温 度と考えられる $199.0^{\circ} \mathrm{C}$ での停滞が250秒以上にわたって観測 された，共晶凝固の継続時間が他の合金系よりも長いという のが特徵である. 本合金系での $\Delta T_{\exp }$ は $0.9 \mathrm{~K}$ であった。 こ の小さな值は他の合金系との違いとして挙げられる.

\section{$3.2 \mathrm{Sn}-\mathrm{X}$ 合金の凝固組織}

希王水でエッチング後, 試料の中央部付近を光学顕微鏡に より観察した.

Fig. 9 に Sn-25 mass\% Pb の凝固組織の観察結果を示す. Fig. 9 a) は低倍率での観察結果である. 白く観察できる相が $(\beta-\mathrm{Sn})$ の初晶であり, そのパターンからデンドライト状に成 長したと判断できる. $(\beta-\mathrm{Sn})$ は体心正方晶構造 $(\mathrm{bct})$ であり, デンドライトの優先成長方向は [110]であることが知られてい $ろ^{28)}$. 必ずしも立方晶のように二次枝が一次枝に対して垂直

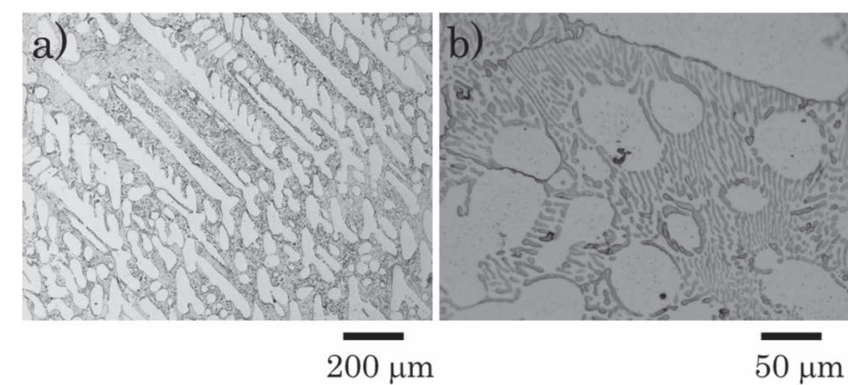

Fig. 9 OM image of solidified structure of $\mathrm{Sn}-25$ mass $\% \mathrm{~Pb}$ alloy. a) low magnification, b) high magnification.
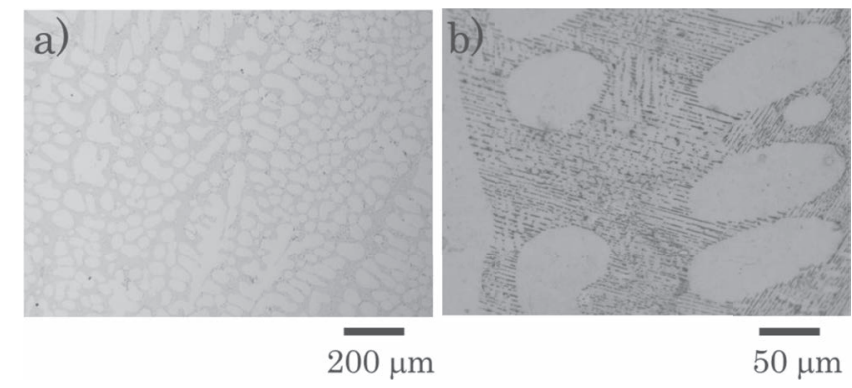

Fig. 10 OM image of solidified structure of Sn-2 mass \% Ag alloy. a) low magnification, b) high magnification.
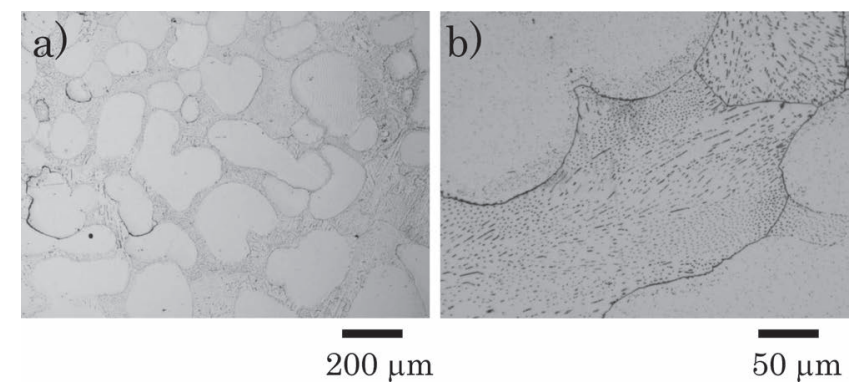

Fig. 11 OM image of solidified structure of Sn-0.4 mass \% Al alloy. a) low magnification, b) high magnification.

であるわけではないようであるが, 少なくとも 1 種類の二次 枝は[110]であると考えられ，主軸とは直交すると考えられ る. Fig. 9 a)からは枝と見える角度は $73^{\circ}$ と読み取れる。これ は $(\beta-\mathrm{Sn})$ のデンドライトの成長が必ずしも観察面内にないこ とが原因であると考えられる。高倍率で観察した結果を Fig. 9 b)に示す. 白く, 丸く見える相が初晶 $(\beta-S n)$ であり, その 周囲を白く見える共晶 $(\beta-\mathrm{Sn})$ と灰色に見える共晶 $(\mathrm{Pb})$ が層状 を呈する共晶組織が埋めている。初晶 $(\beta-\mathrm{Sn})$ の周囲は共晶 $(\mathrm{Pb})$ が覆っていることが多く, 共晶凝固の開始は初晶とは異 なる第二相が初晶上で核生成することと判断できる。

Sn-2.0 mass\% Ag の凝固組織を Fig. 10 に示す. 先と同様, a) は低倍率, b) は高倍率の観察結果である. 初晶 $(\beta-\mathrm{Sn})$ は規 則性を持って並んでいるように見えるが，分断しているもの が多く, $\mathrm{Sn}-\mathrm{Pb}$ 合金ほどははっきりしない. 初晶 $(\beta-\mathrm{Sn})$ の周 囲は層状に見える共晶組織から構成されていることがわかる. 明度から判断すると黒灰色に見える棒状の結晶が共晶 $\mathrm{Ag}_{3} \mathrm{Sn}$ である. 先と同様, 初晶 $(\beta-\mathrm{Sn})$ と共晶 $(\beta-\mathrm{Sn})$ とは明度だけか らは識別できない. なお, 共晶 $\mathrm{Ag}_{3} \mathrm{Sn}$ の整列の向きから, b) の視野内には 2 つの共晶セルが存在していたと判断できる. 
Fig. 11 に Sn-0.4 mass \% Al の凝固組織を示す。粗大で比較 的等方的な初晶 $(\beta-\mathrm{Sn})$ が見られ，それらの配列には規則性は 認められない。共晶組織の部分を拡大して観察した結果が Fig. 11 b)である。初晶の周囲には棒状を呈し黒色の $(\mathrm{Al})$ 相が $(\beta-\mathrm{Sn})$ 相中に分散した共晶組織が観察できる. (Al) 相の方向 の違いから, 観察視野内には共晶セルが複数存在し, その境 界が明瞭に確認できる。

Fig. 12 に Sn-45 mass\% Bi の凝固組織を示す. 低倍率で白 く観察できるものが $(\beta-\mathrm{Sn})$ であることは他の合金とも共通で ある。 その配列にはかなり規則性が認められ，デンドライト 状に成長したことがわかる。拡大した結果が Fig. 12 b)であ るが，初晶の周囲の共晶組織は層状ではあるが形は崩れてい る. また, 初晶 $(\beta-\mathrm{Sn})$ の内部には灰色の粒状の結晶が多数認 められる。これは明度から $(\mathrm{Bi})$ 相であると考えられる。共晶 温度において，初晶 $(\beta-\mathrm{Sn})$ は 21 mass\%の Bi を固溶すること が平衡状態図から予想され ${ }^{15)}$ ，それが室温まで冷却されるに あたって, 初晶 $(\beta-\mathrm{Sn})$ 中に $(\mathrm{Bi})$ が析出したものと考えられる.

Fig. 13 に Sn-0.6 mass\% Cu の凝固組織を示す.ここでも 白く観察できるものが $(\beta-\mathrm{Sn})$ である．初晶 $(\beta-\mathrm{Sn})$ は粗大な粒 状を呈しており，配列からやはりデンドライト状に成長した
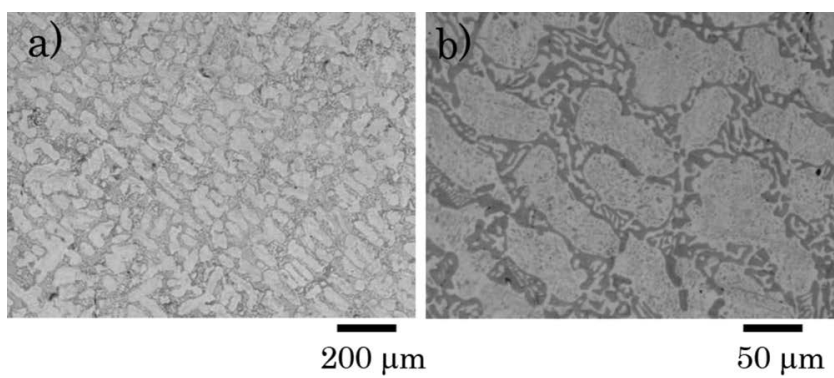

Fig. 12 OM image of solidified structure of $\mathrm{Sn}-45$ mass \% Bi alloy. a) low magnification, b) high magnification.
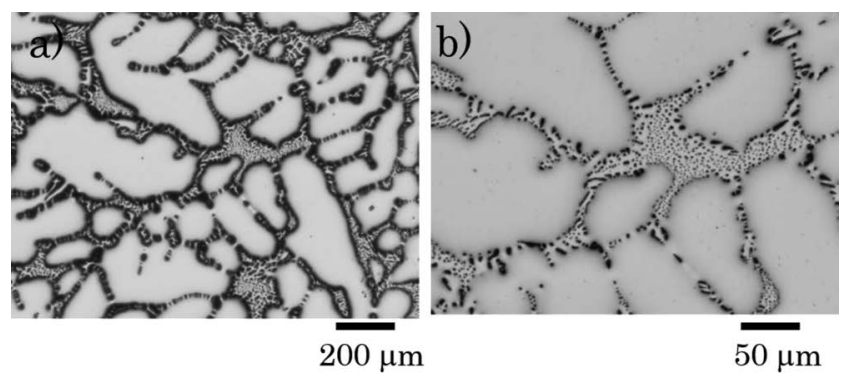

Fig. 13 OM image of solidified structure of Sn-0.6 mass \% Cu alloy. a) low magnification, b) high magnification.
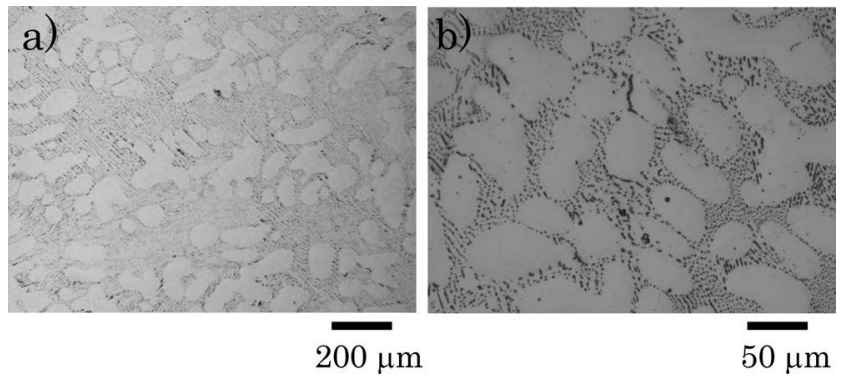

Fig. 14 OM image of solidified structure of $\mathrm{Sn}-6$ mass $\% \mathrm{Zn}$ alloy. a) low magnification, b) high magnification.
と考えられる。拡大して観察したものがFig. 13 b)である。初 晶の間隙に共晶 $(\beta-\mathrm{Sn})$ と棒状の共晶 $\mathrm{Cu}_{6} \mathrm{Sn}_{5}$ からなる共晶組織 が観察できる。

Sn-6 mass \% Zn の凝固組織を Fig. 14 に示す. 初晶 $(\beta-\mathrm{Sn})$ が列をなしている部分があり, デンドライト状に晶出したこ とがわかる．拡大して観察した結果がFig. 14 b)であるが，棒 状に晶出した $(\mathrm{Zn})$ 相が分散したように観察できる。

以上, 全ての合金系について, 過冷融液中で初晶 $(\beta-\mathrm{Sn})$ が 晶出し, その結晶間に共晶組織が形成していた。初晶の整列 の程度や結晶のサイズは合金系によって異なったが, 典型的 な亜共晶合金の組織であった。

\section{3 初晶 $(\boldsymbol{\beta}-\mathrm{Sn})$ の体積率}

Fig. 9 から Fig. 14 に示したように，一部にはデンドライト 状に整列している初晶 $(\beta-\mathrm{Sn})$ もあったが, 試料内に均一に分 布していることは確認できた，初晶をその形態から認識し， 測定視野内に占める面積率を求め, 上部, 中部, 下部の三か 所の平均值を算出した，その結果を Table 2 に示す. Sn-Bi 合 金については上述したように, 初晶 $(\beta-\mathrm{Sn})$ 相の内部に析出し た $(\mathrm{Bi})$ 相が見られた。本研究では共晶温度での初晶 $(\beta-\mathrm{Sn})$ の 体積率を評価するため, これらの析出 $(\mathrm{Bi})$ 相は無視した.

平衡状態図を用いて求めた推定值と, 測定值と推定值との 差を $\Delta f_{\beta-\mathrm{Sn}}$ として記載した。 なお, $\mathrm{Sn}-\mathrm{Al}$ 系については前述 の理由により $\Delta f_{\beta-S n}$ は評価しなかった. $\mathrm{Sn}-\mathrm{X}$ 系合金の多くの 合金系では $\Delta f_{\beta-S n}$ は0 $0.1 \sim 0.3$ の間であったのに対し, $\mathrm{Sn}-\mathrm{Zn}$ 系

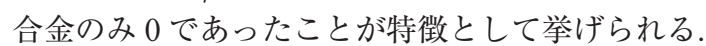

\section{4. 考察}

\section{1 過冷度の定義}

本来，初晶の晶出のための過冷度は，核生成温度と合金の 液相線温度の差として定義される。しかし，そもそも採用す る測定系において核生成温度および液相線温度が精度良く測 定できるかの確認が必要である.

今回のような合金の凝固時の測温実験の場合，熱電対を用 いるのが一般的である. 熱電対による熱履歴測定では一般的 に以下の 3 点の問題点がありうる.

(1)熱接点が測温すべき領域まで十分深く入っていないこと により真值が測定できない可能性がある. (2)高温のためある いは反応性のために，熱電対保護管を薄くできないことから 真值が測定できない可能性がある. (3)熱電対自身を含めた測 温系に誤差があり，真值が測定できないことがある.

Table 2 Volume fraction of primary $(\beta-\mathrm{Sn})$ phase and the difference between the equilibrium values obtained in $\mathrm{Sn}-\mathrm{X}$ hypoeutectic alloys.

\begin{tabular}{cccc}
\hline Alloy & $f_{\beta-\text { Sn }}$ & $f_{\beta-\text { Sn }}^{0}$ & $\Delta f_{\beta-\text { Sn }}$ \\
\hline Sn-25Pb & 0.48 & 0.37 & 0.11 \\
Sn-2Ag & 0.65 & 0.43 & 0.22 \\
$\mathrm{Sn}-0.4 \mathrm{Al}$ & 0.76 & - & - \\
$\mathrm{Sn}-45 \mathrm{Bi}$ & 0.54 & 0.33 & 0.21 \\
$\mathrm{Sn}-0.6 \mathrm{Cu}$ & 0.61 & 0.33 & 0.29 \\
$\mathrm{Sn}-6 \mathrm{Zn}$ & 0.33 & 0.33 & 0.00 \\
\hline
\end{tabular}


今回は極細の熱電対を試料の中心付近になるよう予め固定 したこと，および熱接点近傍はアルミナセメントで薄く保護 したのみとしたことによって, 前述の(1), (2)の問題点は回避 できたと判断できる。したがって，測定した温度データには (3)の測温系の誤差が含まれる。 その誤差は共晶温度で比較す ると $\pm 3 \mathrm{~K}$ の範囲内であった。 このような状況下では, 核生 成時の最下点の温度も復熱後の最高点の温度も真值からずれ ている可能性がある。ここで，最下点の温度だけを採用し， 平衡状態図や計算熱力学に基づく液相線温度との差を過冷度 と定義するよりも, 両方とも実測值とした方が一貫性に優れ, 誤差が少ないと判断できる，そのため, 著者の一人の以前の 研究 ${ }^{29-31)}$ においても，これに従って過冷度を定義した。した がって, 今回も復熱前後の最下点と最高点との温度差を初晶 の核生成のための過冷度とした。

ただし，初晶の核生成のための過冷度が大きい時には試料 内外の熱バランスの関係から液相線温度まで復熱しない可能 性がある。その場合には, 実験的に決定する過冷度を小さく 見積もってしまう危険性がある。しかし，今回の実験では 1 $\mathrm{K}$ 以下の小さな過冷度のグループと， $5 \mathrm{~K}$ 以上の大きな過冷 度のグループで識別できたので, 上記の危険性はあるものの 得られる結論に変わりはないと判断できる.

\section{2 初晶晶出時の過冷度と晶出量}

3.1で述べた各合金での初晶晶出時の過冷度と初晶 $(\beta-\mathrm{Sn})$ の 体積率との関係を Fig. 15 に示す。それぞれのプロットには $\mathrm{Sn}-\mathrm{X}$ 系の第二元素の種類を表示した。筆者ら ${ }^{11)}$ は $\mathrm{Sn}-\mathrm{Pb}$ 合 金を用いて, 初晶 $(\beta-\mathrm{Sn})$ の晶出時の過冷度の大きさと晶出す る $(\beta-\mathrm{Sn})$ の体積率との関係を調べた，その結果, $\mathrm{Sn}-\mathrm{Pb}$ 合金 では過冷度が小さくても平衡状態図からの予想值よりも大き いこと, また過冷度が大きい方が晶出量が大きくなる傾向が あることを示した，今回の結果は，過冷度が大きいほど晶出 量が大きくなる，という単純な結果ではないが，過冷度と晶 出量との間には何らかの関係があることを示唆していると考 えられる.

ここで, $\mathrm{Sn}-\mathrm{Zn}$ 系合金だけが，過冷度が非常に小さくかつ初 晶 $(\beta-\mathrm{Sn})$ の晶出量が平衡状態図からの予測值に合致したとい

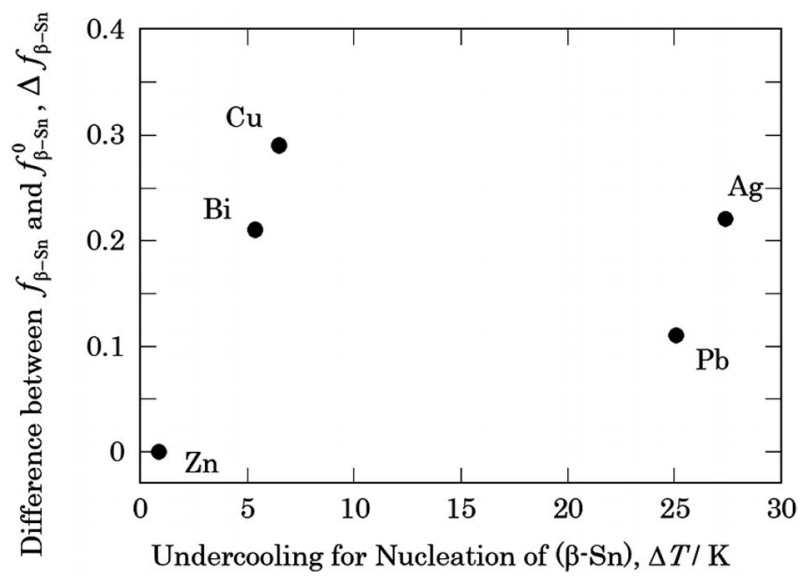

Fig. 15 Relationship between undercooling for nucleation of primary $(\beta-\mathrm{Sn})$ phase and the difference between volume fraction of primary $(\beta-\mathrm{Sn})$ phase obtained in $\mathrm{Sn}-\mathrm{X}$ alloys and their equilibrium values.
う，極めて特異な例であることがわかる。

\section{$4.3 \mathrm{Sn}-\mathrm{Zn}$ が特異である理由}

\subsection{1 ( $\beta-\mathrm{Sn})$ 相の核生成が容易である理由の推定}

古典的核生成理論は純物質の核生成の考え方であるが，こ の考え方を利用して, $\mathrm{Sn}-\mathrm{X}$ 系の初晶 $(\beta-\mathrm{Sn})$ の核生成・成長 について定性的に検討を加える.

\section{(1) 純物質の核生成}

半径 $r$ の球形の固相状の物体が, ある過冷度の融体中に生 成する場合の自由エネルギー変化は次のように示せる ${ }^{32,33)}$.

$$
\Delta G=-\frac{4}{3} \pi r^{3} \Delta G_{\mathrm{V}}+4 \pi r^{2} \sigma
$$

ここで, 第一項の $\Delta G_{\mathrm{V}}$ は過冷度 $(\Delta T)$ の過冷融体から固相にな る際の自由エネルー変化であり, 凝固の駆動力に相当する. これは次のように示せ，過冷度に正比例する。

$$
\Delta G_{\mathrm{V}}=\frac{L \cdot \Delta T}{T_{\mathrm{M}}}
$$

ここで，Lは凝固潜熱であり， $T_{\mathrm{M}}$ は融点である.

[1]式の第一項は負であり，固相になることによって自由 エネルギーは減少する。 また，第二項の $\sigma$ は固液界面エネル ギーである，固相状の物体ができることにより，界面を形成 する仕事に相当する，第二項は正であり，固相になることに よって自由エネルギーは増加する。［1]式を模式的に図示し たものが Fig. 16 であり，［1]式の第一項と第二項の合計とし て示される．合計のエネルギー変化は $r^{*}$ で最大值をとる， $r^{*}$ に達するまでは固相状の物体ができても自由エネルギーは増 加するために，固相状の物体は消滅する。しかし，たまたま $r^{*}$ を超える固相状の物体が形成すれば，それ以降は， $\Delta G$ は 減少に転ずるために, 自発的に固相への変態が進む. ここで, r゙が小さいほど，偶然にそのサイズの固相状の物体ができる 可能性が高くなるために核生成が起こりやすいと考えられる.

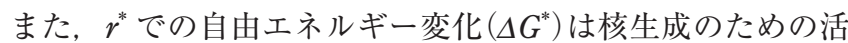
性化エネルギーに対応すると考えられるが, この值が低く

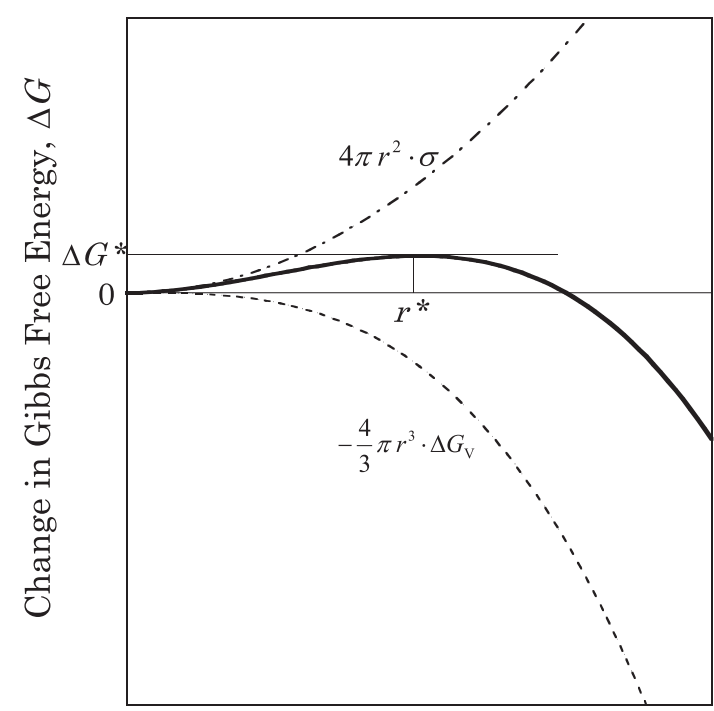

Radius, $r$

Fig. 16 A schematic diagram for Gibbs free energy change for transformation from liquid to solid in undercooled melt. 
なっても核生成が起こりやすくなると考えられる。

\section{(2) Sn-X 系への適用の試み}

純物質の場合, 液相から固相への自由エネルギー変化量は [2]式のように示せた。合金の場合, 晶出する固相は溶質元 素を分配係数に応じて固溶するものの，今回の合金系である $\mathrm{Sn}-\mathrm{X}$ 系では $(\beta-\mathrm{Sn})$ 相である。溶質の種類と量によって凝固 潜熱は変化する可能性はあるが, ここでは変わらないと考え る.また, 核は非常に小さいので, 固相率の増加の温度依存 性は無視できるものとする，以上のような仮定を置けば，固 相への変態の駆動力は合金の種類によらず，過冷量の増加に より増加すると考えられる.

Fig. 15 を過冷度の大小で比較したものを Fig. 17 に示す. ここでは過冷度が小さい場合を $\Delta T_{1}$, 大きい場合を $\Delta T_{2}$ とし て表示した．前述のように，[1]式の $\Delta G_{\mathrm{V}}$ は過冷度が大きく なると大きくなるため, $\Delta T_{2}$ の場合の方が $[1]$ 式の第 1 項は より負側に表示される。一方, 界面を形成するための固液界 面エネルギーは温度に大きく依存しないと考えられるために, 一点鎖線で示すように過冷度には依存しない.したがって, 合計の自由エネルギー変化は過冷度の小さい $\Delta T_{1}$ の時の太実 線に対して, 過冷度の大きい $\Delta T_{2}$ の太破線のように変化する. $r^{*}, \Delta G^{*}$ ともに小さくなるため, 核生成は過冷度の大きい方 が起こりやすいと考えられる.

今回の研究の範囲では, $\mathrm{Sn}-\mathrm{Zn}$ 以外と比較して, $\mathrm{Sn}-\mathrm{Zn}$ 合 金では $(\beta-\mathrm{Sn})$ の晶出時の過冷度が非常に小さかった。つまり, 過冷量が小さくても容易に核生成したわけであり, これは Fig. 17 を用いた上記の議論とは矛盾する. [1]式に示した通 り, 核生成には第 1 項の固相状の体積に依存する項と第 2 項 の固相状の表面積に依存する項の 2 つのみが関与する。今, 第 1 項は逆方向に作用するので, 第 2 項が大きく変化して, 全体としては核生成が容易になるように，r゙が小さく，また は $\Delta G^{*}$ が小さくなったと考えられる。これを模式的に示した ものが, Fig. 18 である. 基準となる過冷度の值 $\left(\Delta T_{1}\right)$ と固液 界面エネルギーの值の基準值 $\left(\sigma_{1}\right)$ の時の核生成に伴う自由エ ネルギー変化を太実線で示す。それに対し, 過冷度が小さく なるが $\left(\Delta T_{3}\right)$, 界面エネルギーの值が大幅に小さくなった $\left(\sigma_{2}\right)$ 場合の自由エネルギー変化を太い一点鎖線で示す. 仮に過冷

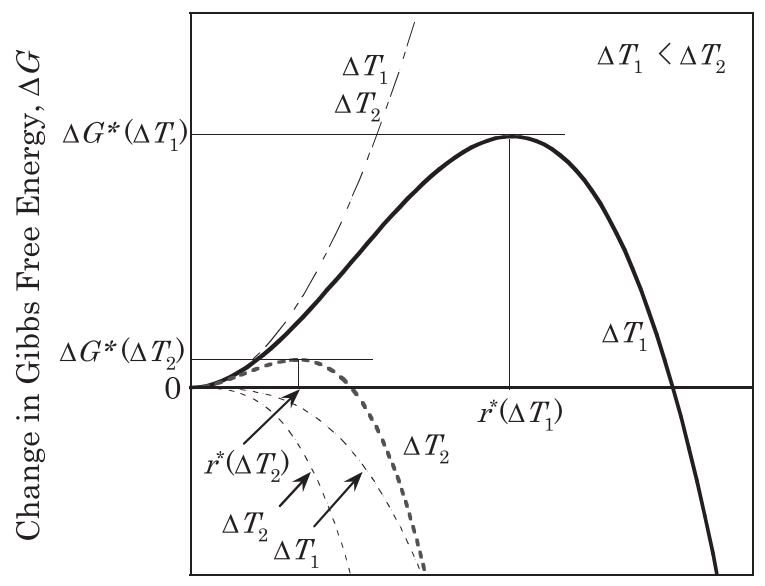

Radius, $r$

Fig. 17 Schematic diagrams for Gibbs free energy change for nucleation in undercooled melt as a function of undercooling.
度が $\Delta T_{3}$ で示すように小さくなっても, 界面エネルギーの值 が $\sigma_{2}$ になり，[1]式の第 2 項が細い破線から太い破線のよう に変化すれば，核生成のための臨界点は矢印で示したように 左下へ大きく移動する。このように変化すれば，仮に過冷度 が小さくなっても，核生成は容易になると考えることができ る.

固液界面エネルギーが大幅に小さくなるには，(a)不均一核 生成の可能性, (b) Zn が合金元素として添加されることによ る効果, の 2 つ可能性が考えられる.

(a) 不均一核生成の可能性

不均一核生成の核となりうるものとして，今回の合金系や 採用した実験操作からは，添加された合金元素の酸化物が考 えられる. それぞれの元素の酸化物の標準生成自由エネル ギーの值が酸化物生成の難易度の目安となる。これは一般に 次式のような温度依存性を加味した式が報告されている ${ }^{34)}$.

$$
\Delta G=A+B T \quad(\mathrm{~kJ} / \mathrm{mol})
$$

今回用いた合金元素について，上式の $A$ および $B$ の值を Table 3 に列挙する. ここでは液相の純金属 Xが 1 モルの酸 素と反応して固相の酸化物になる反応の值を用いた。ただし, $\mathrm{Ag}_{2} \mathrm{O}$ については液相の $\mathrm{Ag}$ が反応する場合のデータが見当た らなかったので, 固相の $\mathrm{Ag}$ が固相の $\mathrm{Ag}_{2} \mathrm{O}$ になる反応の自由 エネルギー変化の值を用いた。ほとんどのデータが高温での 值であるが，低温まで外挿できるものと考えた。 200-700 K の範囲で, 酸化物の標準生成自由エネルギーを Fig. 19 に示

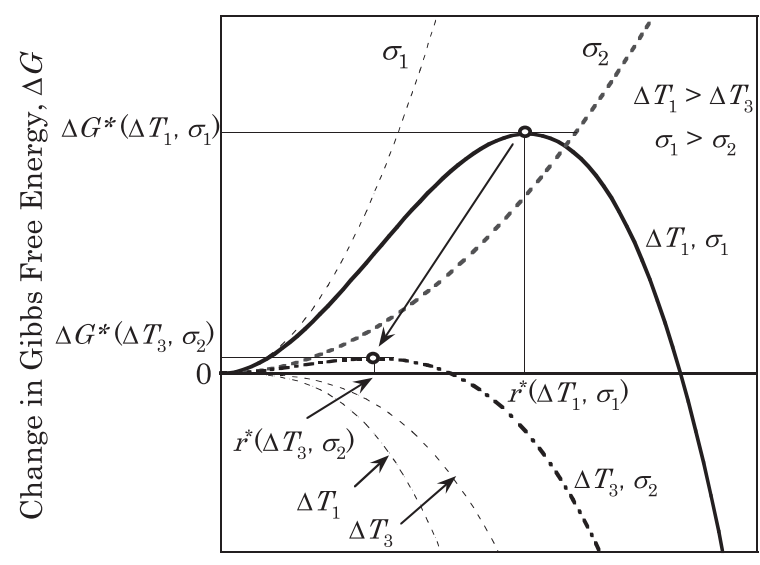

Radius, $r$

Fig. 18 Schematic diagrams for Gibbs free energy change for nucleation in undercooled melt as functions of undercooling and surface energy.

Table 3 Standard free energy change for the formation of oxides. $\Delta G^{0}=A+B T\left(\mathrm{~kJ} \mathrm{~mol}^{-1}\right)$

\begin{tabular}{ccc}
\hline Oxide & $A$ & $B$ \\
\hline $\mathrm{SnO}_{2}$ & -579.81 & 0.20409 \\
$2 \mathrm{PbO}$ & -439.34 & 0.20040 \\
$2 \mathrm{Ag}_{2} \mathrm{O}$ & -61.53 & 0.13405 \\
$\frac{2}{3} \mathrm{Al}_{2} \mathrm{O}_{3}$ & -1126.89 & 0.21881 \\
$\frac{2}{3} \mathrm{Bi}_{2} \mathrm{O}_{3}$ & -390.74 & 0.19399 \\
$2 \mathrm{Cu}_{2} \mathrm{O}$ & -380.11 & 0.17735 \\
$2 \mathrm{ZnO}$ & -712.54 & 0.21591 \\
\hline
\end{tabular}




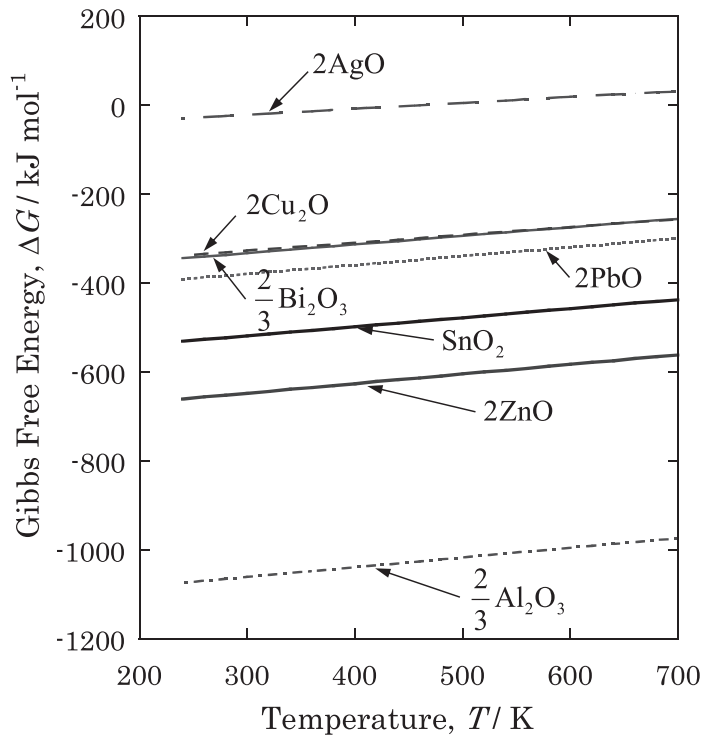

Fig. 19 Standard formation energy for oxides concerning to the $\mathrm{Sn}-\mathrm{X}$ alloys used in this study.

す．これらは純物質が酸化する時の值であり, Snの溶媒に溶 質として含まれる場合の挙動ではない. しかし, 酸化の目安 にはなると考えられる。この図によると，今回用いた $\mathrm{Sn}-\mathrm{X}$ 系合金の中では, 溶媒の $\mathrm{Sn}$ よりも酸化しやすい元素は $\mathrm{Al}$ と $\mathrm{Zn}$ であることがわかる.よって, $\mathrm{Sn}$ 合金中では $\mathrm{Al}_{2} \mathrm{O}_{3}$ あるい は $\mathrm{ZnO}$ が存在する可能性がある.

$\mathrm{Sn}-\mathrm{Al}$ 合金の熱履歴は Fig. 5 に示したように, 初晶 $(\beta-\mathrm{Sn})$ の生成に伴う過冷度は 10.9 Kであり, 大きかった。 これから, $\mathrm{Sn}-\mathrm{Al}$ 合金融液中に $\mathrm{Al}_{2} \mathrm{O}_{3}$ は生成していたとしても，これは $(\beta-\mathrm{Sn})$ に対して有効な核生成サイトとして作用しなかったと 考えられる．また，本実験ではすべての合金をアルミナるつ ほで溶解し，アルミナ製の絶縁管に通した熱電対により熱履 歴を測定していた．仮に $\mathrm{Al}_{2} \mathrm{O}_{3}$ が不均一核として有効であれ ば，すべての合金系に対して小さな過冷度のデータが得られ たはずである．以上より， $\mathrm{Al}_{2} \mathrm{O}_{3}$ は $(\beta-\mathrm{Sn})$ 相の核生成を容易に するとは考えられない。

一方, $\mathrm{Sn}-\mathrm{Zn}$ 合金については, 生成した $\mathrm{ZnO}$ が $(\beta-\mathrm{Sn})$ 相の 核生成サイトとして作用したことは十分に考えられる。 しか し, $\mathrm{ZnO}$ は非晶質になると報告している例35)もあり， $(\beta-\mathrm{Sn})$ 相の核生成サイトになっているかどうかについてはさらに詳 細な研究を進める必要がある.

(b) 合金元素としての Zn の効果

今回用いた溶質元素のうち, 平衡状態図によって共晶温度 での最大固溶量がゼロとみなせるのは, $\mathrm{Ag}, \mathrm{Cu}$ である。他の, $\mathrm{Pb}, \mathrm{Bi}, \mathrm{Zn}$ は程度の差はあるものの, 固溶量が明記されてい $3^{12,13,15-17)}$. Sn-Zn 系については, 共晶温度で最大固溶を示 し，その值は 0.3 mass\%である ${ }^{17)}$ 。また，共晶温度で Znの 固液間での平衡分配倸数を算出すると, $k=0.03$ となり, 比較 的小さな值である.

例えば溶鉄に酸素や硫黄がわずかに添加されることによっ て，穴の表面張力が大幅に低下することが知られている ${ }^{36)}$. この例のように, わずかに固相に固溶することによって, 固 液間の界面エネルギーを低下させる可能性がある。また，凝 固しつつあるとき, 固液界面で局所平衡が成り立つと考えら
れるが，上述のように $\mathrm{Zn}$ の平衡分配倸数は小さいために, 固 液界面の液相濃度が高くなることによって, 界面の物性值が 変化することも考えられる，さらに，固液界面で $\mathrm{Zn}$ 原子が 吸着することによって, 局所平衡值以上に界面で $\mathrm{Zn}$ 濃度が 高くなり, 界面の物性值がさらに大きく変化することも考え られる。

一方, 固液界面エネルギーには直接関係ないが, $\mathrm{Zn}$ が固溶 することによって， $(\beta-\mathrm{Sn})$ 相が固相になりやすくなる可能性 がありうる。これは過冷合金融夜中での液－固の変態の自由 エネルギー変化が大きくなることに対応し, 液相中での $\mathrm{Sn}$ 原 子と Zn 原子との相互作用が大きくなること, もしくは固相 中での $\mathrm{Sn}$ 原子と Zn 原子の相互作用が小さくなることに相当 する.これらの結果として平衡状態図があるが, $\mathrm{Sn}-\mathrm{Zn}$ 系の 平衡状態図の形は他の合金系の形と大きな違いは認めにくい. しかし, 上記の様な液相内, 固相内での相互作用の差が初晶 $(\beta-\mathrm{Sn})$ 相の核生成に何らかの作用をした可能性は否定できな い.

以上，(b)で述べた可能性はいずれも推測の域を出ないも のである. 今後, 各項目について実験的, 理論的に検討する 必要がある。

\subsubsection{Sn-X 系合金の初晶 ( $\beta$-Sn) 相の体積率}

本研究では $\mathrm{Sn}-\mathrm{X}$ 合金の凝固に扔いて, 初晶 $(\beta-\mathrm{Sn})$ の体積 率が平衡值よりも過大である, という事象に普遍性があるか について検討した．Xが $\mathrm{Pb}, \mathrm{Ag}, \mathrm{Bi}, \mathrm{Cu}$ については上記の 事象が当てはまるものの，Znについては当てはまらないこと が明らかになった. 同時に $\mathrm{Sn}-\mathrm{Zn}$ 系合金では初晶 $(\beta-\mathrm{Sn})$ の核 生成のための過冷度が他の合金系と比較して極めて小さいこ とも明らかになった，初晶の核生成のための過冷度が小さい ということと, 初晶の晶出量が平衡值通りである, というこ とが直接対応することかどうかは未だに不明であるが，何ら かの影響を及ぼしていると思われる。

$\mathrm{Sn}-\mathrm{X}$ 系合金では Zn を除いて多くの合金系で初晶 $(\beta-\mathrm{Sn})$ の 体積率が過大であることが一般的であった，過大に晶出する 原因を解明し，平衡状態図通りに制御する方策を明らかにす ることが研究プロジェクトの目標となる. 過大に晶出する原 因は現状では不明であるが, Sn-Zn 系に扔ける Zn の効果を 解明することが過大に晶出する原因を明らかにするための手 掛かりになると思われる. 実験的, 理論的に解明することが 今後の課題である.

\section{5. 結 論}

$\mathrm{Sn}-\mathrm{X}$ 系共晶合金の亜共晶組成の合金を用いて，るつぼ内で 一定冷却速度の下で凝固させた際の, 核生成のための過冷度 と初晶体積率との関係を実験的に調査した。 その結果, 以下 の 4 点が明らかになった。

(1) $\mathrm{X}$ として $\mathrm{Pb}, \mathrm{Ag}, \mathrm{Al}, \mathrm{Bi}, \mathrm{Cu}$ を用いた場合は, 初晶 $(\beta-\mathrm{Sn})$ 相の晶出のための過冷度は $5 \mathrm{~K}$ 以上であり大きかった のに対し， X として Zn を用いた場合は $0.9 \mathrm{~K}$ と極めて小さ かった.

（2） $\mathrm{X}$ として $\mathrm{Pb} ， \mathrm{Ag} ， \mathrm{Bi} ， \mathrm{Cu}$ を用いた場合は，初晶 $(\beta-\mathrm{Sn})$ 相の体積率はそれぞれの平衡状態図から「てこの法則」を用い 
て予測した值よりも大きかった。一方，Zn を用いた場合は, 予測值と極めて良い一致を示した。

(3) $\mathrm{Sn}-\mathrm{Zn}$ 系合金でのみ初晶晶出のための過冷度が小さく なり, 晶出する初晶 $(\beta-\mathrm{Sn})$ の体積率が平衡状態図通りとなっ た原因は不明である。

(4) $\mathrm{Sn}-\mathrm{Zn}$ 系合金では初晶晶出のための過冷度が小さく なったことから，核生成を容易にする何らかの作用があった ものと推定される.

\section{文献}

1) S. K. Kang and A. K. Sarkhel: J. Electron. Mater. 23(1994) 701707.

2) K. Suganuma: Scr. Mater. 38(1998) 1333-1340.

3) M. E. Loomans and M. E. Fine: Metall. Mater. Trans. A 31A (2000) 1155- 1162

4) I. E. Anderson, J. C. Foley, B. A. Cook, J. Harringa, R. L. Terpstra and O. Unal: J. Electron. Mater. 30 (20001) 1050-1059.

5) H. Springer, A. Szczepaniak and D. Raabe: Acta Mater. 96 (2015) 203-211.

6) Y.-P. Su, C.-S. Wu and F.-Y. Ouyang: J. Electron. Mater. 45 (2016) 30-37.

7) J. W. Xian, S. A. Belyakov and C. M. Gourlay: J. Electron. Mater. 45(2016) 69-78

8) L. Snugovsky, P. Snugovsky, D. D. Perovic, T. Sack and J. W. Rutter: Mater. Sci. Technol. 21 (2005) 53-60.

9) Y. Takamatsu, H. Esaka and K. Shinozuka: J. Japan Inst. Metals 75(2011) 341-347.

10) Y. Takamatsu, H. Esaka and K. Shinozuka: J. Electron. Mater. 41 (2012) 2035-2044.

11) R. Yoshimura, H. Esaka and K. Shinozuka: Mater. Sci. Forum 827-829 (2015) 73-77.

12) T. B. Massalski: Binary Phase Diagrams, (ASM Metals Park, Ohio, USA, 1987) pp. 1845-1848.

13) T. B. Massalski: Binary Phase Diagrams, (ASM Metals Park, Ohio, USA, 1987) pp. 69-71.

14) T. B. Massalski: Binary Phase Diagrams, (ASM Metals Park,
Ohio, USA, 1987) pp. 167-170

15) T. B. Massalski: Binary Phase Diagrams, (ASM Metals Park, Ohio, USA, 1987) pp. 540-541.

16) T. B. Massalski: Binary Phase Diagrams, (ASM Metals Park, Ohio, USA, 1987) pp. 964-965.

17) T. B. Massalski: Binary Phase Diagrams, (ASM Metals Park, Ohio, USA, 1987) pp. 2082-2086.

18) Y. Nagatomo, H. Esaka and K. Shinozuka: J. Japan Inst. Metals 79(2015) 280-286.

19) A. G. C. Gwyer: Z. Anorg. Chem. 49(1906) 311-316.

20) É. Bonnier, F. Durand and G. Massart: C. R. Acad. Sci. Paris, 259(1964) 380-383.

21) H. Ohtani and K. Ishida: J. Electron. Mater. 23 (1994) 747-755.

22) B.-J. Lee, C.-S. Oh and J.-H. Shim: J. Electron. Mater. 25 (1994) 983-991.

23) J. Vizdal, M. H. Braga, A. Kroupa, K. W. Richter, D. Soares, L. F. Malheiros and J. Ferreira: Calphad 31(2007) 438-448.

24) M. H. Braga, J. Vizdal, A. Kroupa, J. Ferreira, D. Soares and L F. Malheiros: Calphad 31 (2007) 468-478.

25) W. Oelson and K. F. Golücke: Arch. Eisenhüttenwes. 29 (1958) 689-698.

26) Y. Miyauchi, H. Esaka, M. Tamura and K. Shinozuka: J. Japan Inst. Metals 72 (2008) 804-811.

27) T. Sakuma: Zairyoukensaho, (The Japan Inst. Metals, Sendai, Japan, 1978) 29-31.

28) W. Kurz and D. J. Fisher: Fundamentals of Solidification, (Trans Tech Publication, Aedermannsdorf, Switzerland, 1992) pp. 63-92.

29) H. Esaka, T. Shimada, S. Mizoguchi and H. Kajioka: J. Japan Inst. Metals 54(1990) 1099-1105.

30) H. Esaka, T. Shirakami, T. Mizoguchi and S. Ogibayashi: Tetsuto-Hagané 81 (1995) 631-636.

31) T. Kajitani, H. Esaka, M. Wakoh, H. Misumi and S. Ogibayashi: Tetsu-to-Hagané 81 (1995) 1055-1060.

32) J. A. Dantzig and M. Rappaz: Solidification, (EPFL Press, Lausanne, Switzerland, 2009) pp. 249-285.

33) M. E. Glicksman: Principles of Solidification, (Springer, New York, USA, 2011) pp. 273-301.

34) K. Itagaki: Extractive Metallurgy, (The Japan Institute of Metals, Maruzen, Sendai, 1999) pp. 175-188.

35) H. Kato and T. Nakahara: Mater. Trans. 54(2013) 2109-2118.

36) T. Tanaka and S. Hara: Materia Japan 36(1997) 47-54. 